\title{
SOIL EXCHANGEABLE CATIONS, SUGARCANE PRODUCTIONAND NUTRIENT UPTAKE AFTER WASTEWATER IRRIGATION
}

\author{
Rafael Marques Pereira Leal ${ }^{1,2}$; Lilian Pittol Firme ${ }^{1,2}$; Célia Regina Montes ${ }^{3,2}$; Adolpho José \\ Melfi' ${ }^{2,4}$; Sonia Maria De Stefano Piedade ${ }^{5}$ \\ ${ }^{1}$ USP/ESALQ - Programa de Pós-Graduação em Solos e Nutrição de Plantas. \\ ${ }^{2}$ USP/Núcleo de Pesquisa em Geoquímica e Geofísica da Litosfera, C.P. 09 - 13418-900 - Piracicaba, SP - Brasil. \\ ${ }^{3}$ USP/CENA - Lab. de Geoprocessamento e Tratamento de Imagens, C.P. 96 - 13400-970 - Piracicaba, SP - \\ Brasil. \\ ${ }^{4}$ USP/ESALQ - Depto. de Ciência do Solo, C.P. 09 - 13418-900 - Piracicaba, SP - Brasil. \\ ${ }^{5}$ USP/ESALQ - Depto. de Ciências Exatas, C.P. 09 - 13418-900 - Piracicaba, SP - Brasil. \\ *Corresponding author <ajmelfi@usp.br>
}

\begin{abstract}
Wastewater irrigation may benefit agricultural crops with water and essential nutrients (mainly nitrogen), also affecting soil chemistry. The effects of effluent irrigation on yield, stalk nutrient uptake and on soil chemistry over 16 months were studied in a sugarcane (Saccharum spp.) crop growing on an Oxisol in Lins, State of São Paulo, Brazil. Irrigated plots received 50\% of the recommended mineral-N fertilization and 100, 125, 150 or $200 \%$ of the crop water demand, while control plots received neither additional $\mathrm{N}$ nor water. The high sodium content of effluent resulted in $\mathrm{Na}$ inputs as high as $6.2 \mathrm{t} \mathrm{ha}^{-1}$, along with $1497 \mathrm{~kg} \mathrm{~N} \mathrm{ha}^{-1}$ and $628 \mathrm{~kg} \mathrm{~K} \mathrm{ha}^{-1}$. All the effluent plots except the T125 treatment had higher yields (up to $247 \mathrm{t} \mathrm{ha}^{-1}$ ) than the control $\left(153 \mathrm{t} \mathrm{ha}^{-1}\right.$ ). Significant amounts of $\mathrm{N}$ (up to $597 \mathrm{~kg} \mathrm{ha}^{-1}$ ) and $\mathrm{K}$ (up to $546 \mathrm{~kg} \mathrm{ha}^{-1}$ ) were exported by the plant harvest. Additions of nutrients and $\mathrm{Na}$ via irrigation were not compensated by stalk growth, causing a low recovery of $\mathrm{N}, \mathrm{P}, \mathrm{Ca}, \mathrm{Na}$, and showing the relative over $\mathrm{N}$ fertilization of the crop. Changes in soil $\mathrm{pH}, \mathrm{H}+\mathrm{Al}, \mathrm{Ca}, \mathrm{Mg}$ and $\mathrm{K}$ were small, whereas $\mathrm{Na}$ accumulated over time with irrigation. The treated wastewater irrigation is expected to gain increased importance, requiring careful considerations involving the adequate balance between nutritional inputs via irrigation and optimal plant productivity requirements.
\end{abstract}

Key words: Saccharum spp., water reuse, land disposal, nutrient cycling

\section{CÁTIONS TROCÁVEIS DO SOLO, PRODUÇÃO E EXTRAÇÃO DE NUTRIENTES PELACANA-DE-AÇÚCARAPÓS IRRIGAÇÃO COMÁGUA RESIDUÁRIA}

\begin{abstract}
RESUMO: A irrigação com águas residuárias pode beneficiar as culturas agrícolas com água e nutrientes essenciais (especialmente nitrogênio), afetando também a química do solo. Os efeitos da irrigação por 16 meses com efluente de esgoto na produtividade, extração de nutrientes pelo colmo, e nos atributos químicos do solo, foram estudados em um Latossolo cultivado com cana-de-açúcar (Saccharum spp.), situado em Lins, São Paulo. As parcelas irrigadas receberam 50\% do N mineral recomendado e $100,125,150$ ou $200 \%$ da demanda hídrica da cultura, enquanto o controle não recebeu N mineral e nem água. As elevadas concentrações de sódio do efluente ocasionaram um aporte de $\mathrm{Na}$ de até $6,2 \mathrm{t} \mathrm{ha}^{-1}$, juntamente com até $1497 \mathrm{~kg} \mathrm{~N} \mathrm{ha}^{-1}$ e $628 \mathrm{~kg} \mathrm{~K} \mathrm{ha}^{-1}$. Todas as parcelas irrigadas, com exceção do T125, apresentaram maior produtividade (até $247 \mathrm{t} \mathrm{ha}^{-1}$ ) do que o controle $\left(153 \mathrm{t} \mathrm{ha}^{-1}\right)$. Quantidades expressivas de $\mathrm{N}$ (até $597 \mathrm{~kg} \mathrm{ha}^{-1}$ ) e de $\mathrm{K}$ (até $546 \mathrm{~kg} \mathrm{ha}^{-1}$ ) foram exportadas através da colheita da cultura. As adições de nutrientes e de $\mathrm{Na}$ via irrigação não foram compensadas pelo crescimento da planta, ocasionando uma baixa recuperação de N, P, Ca e Na, evidenciando uma excessiva fertilização da planta (N). Alterações no solo de $\mathrm{pH}, \mathrm{H}+\mathrm{Al}, \mathrm{Ca}, \mathrm{Mg}$ e $\mathrm{K}$, foram de pequena magnitude, enquanto houve acúmulo de $\mathrm{Na}$ trocável ao longo do tempo nos tratamentos irrigados. A irrigação com águas residuárias deverá adquirir importância crescente, exigindo atenção detalhada ao balanço entre o aporte de nutrientes via irrigação e as quantidades requeridas para a otimização da produtividade da cultura.
\end{abstract}

Palavras-chave: Saccharum spp., reuso de água, disposição agrícola, ciclagem de nutrientes 


\section{INTRODUCTION}

Population growth and urban sprawl are increasing the demand for good quality municipal waters and pressuring many Brazilian municipalities to adequately treat their wastewater. As a consequence, domestic wastewater treatment plants (WWTPs), especially stabilization ponds, are increasingly adopted in many small to medium cities in São Paulo State. Agricultural land has been considered as an interesting and practical alternative to the disposal of treated wastewater, avoiding discharge to natural waterways, and the associated risks of eutrophication (Feigin et al., 1991). Agriculture can readily use the water and plant nutrients from the wastewater, but this may cause some potential problems, including nitrates and salts leaching to the groundwater or accumulation of sodium, salts, pathogens and trace contaminants in the soil (Bond, 1998). In most cases, irrigation of crops with treated domestic wastewaters alters soil chemistry, causing: (i) slight decrease on soil acidity; (ii) marked increases in Na concentrations and exchangeable sodium percentage (ESP); (iii) mixed effects on soil $\mathrm{K}$ and $\mathrm{Mg}$ and; (iv) increase in exchangeable $\mathrm{Ca}$ (Fonseca et al., 2007).

São Paulo State has approximately $60 \%$ of the Brazil's sugarcane production (FNP Cosultoria \& Comércio, 2006), with the crop mainly dependent on rain to meet plant water needs. Production is increasing due to the importance of ethanol for fuel in the national and international markets. In this context, the use of wastewater for irrigation might assist this crop agro-industry expansion.

The main objective of the present study was to evaluate the effects of secondary-treated wastewater on soil chemistry, plant productivity and nutrients uptake in a sugar crop wastewater irrigated during 16 months.

\section{MATERIAL AND METHODS}

\section{Study area}

The experimental field of $7.500 \mathrm{~m}^{2}$ was located in Lins, State of São Paulo, Brazil (49 $50^{\prime}$ W; $22^{\circ} 21^{\prime}$ $\mathrm{S}$; average altitude: $440 \mathrm{~m}$ ), beside a WWTP. The plant treats the wastewater by three anaerobic ponds (primary treatment) followed by three facultative ponds (secondary treatment), also known as the Australian system. The region has a tropical wet climate, with annual rainfall from 1,100 to $1,300 \mathrm{~mm}$. The clayey sand texture local soil was classified as Typic Haplustox (Latossolo Vermelho Distrófico Típico by Brazilian classification), cropped with 'RB 72454' sugarcane (Saccharum spp.) variety. Total rainfall during experiment was $1,292 \mathrm{~mm}$.

\section{Crop and irrigation management}

Before planting, the site was cultivated with Crotalaria juncea. Sugarcane was planted in March 2005 , with $1.4 \mathrm{~m}$ between the rows. Fertilization followed regional recommendations of Raij et al. (1996): Plots received $15 \mathrm{~kg} \mathrm{ha}^{-1}$ of $\mathrm{N}$ (ammonium nitrate), except the control; $52 \mathrm{~kg} \mathrm{ha}^{-1}$ of $\mathrm{P}$ (simple superphosphate), and $66 \mathrm{~kg} \mathrm{ha}^{-1}$ of $\mathrm{K}$ (potassium chloride), manually distributed along the furrows at planting. The crop was irrigated from May 2005 to August 2006, with the crop harvest in the end of September 2006.

The crop was watered by drip irrigation giving $3.8 \mathrm{~L} \mathrm{~h}^{-1}$. Irrigation management was based on the critical volumetric water content in the $0-60 \mathrm{~cm}$ layer. The matrix potential $\left(\Psi_{\mathrm{m}}\right)$ was monitored every 2 days by tensiometers installed at $0-20,20-40$ and $40-60 \mathrm{~cm}$ layers. The $\Psi_{\mathrm{m}}$ values obtained together with the local water retention curve data were fit to the Genutchen equation (Genutchen, 1980) to calculate the volumetric water content. Plants were irrigated when $\Psi_{\mathrm{m}}$ was less than $-40 \mathrm{kPa}$, corresponding to a volumetric water content of approximately $60 \%$ of the available water capacity in the top 0-60 cm layer. Once the need for irrigation was defined, wastewater was applied at the same time for all irrigated treatments. When compared to T100, at higher irrigation rates (T125, T150 and T200), the time of application was proportional to the extra volume applied.

The experiment was arranged in a split plot design, with irrigation rates as the main plots and sampling time as the split plot, and five treatments and four blocks. Treatments were: (i) Control, with no irrigation and no addition of mineral-N fertilizer; (ii) T100T200, addition of $50 \%$ of the recommended mineral$\mathrm{N}$ fertilization and irrigation with $100,125,150$, or $200 \%$ of the crop water demand. Each plot was 280 $\mathrm{m}^{2}(40 \mathrm{~m} \times 7 \mathrm{~m})$ and $126 \mathrm{~m}^{2}$ excluding borders.

The specific design of the present research, involving irrigations rates ranging from 100 to $200 \%$ of the crop water needs, was intended to apply "two opposite philosophies" of land application: one disposing the maximum amount of effluent in the smallest possible area (wastewater applications higher than 100\%): other disposing according to the plant water demand (T100) and represents wastewater agricultural use with the primary objective to enhance agricultural production, avoiding the loss of nutrients and the potential for pollution.

\section{Sampling, preparation and analysis}

Soil sampling was carried out in February 2005 (before planting), December 2005 (eight months of irrigation) and September 2006 (after sugarcane harvest and 16 months of irrigation). Samples were col- 
lected at $0-10,10-20,20-40,40-60,60-80$ and $80-$ $100 \mathrm{~cm}$ depths. Determinations of $\mathrm{pH}$ and $\mathrm{H}+\mathrm{Al}$ were carried out as described by Raij et al. (2001), whereas $\mathrm{Ca}, \mathrm{Mg}, \mathrm{K}, \mathrm{Al}$, and $\mathrm{Na}$ were determined according to the methods of Embrapa (1999). After air-drying and sieving $(2 \mathrm{~mm})$, the $\mathrm{pH}$ was determined in a $0.01 \mathrm{~mol}$ $\mathrm{CaCl}_{2} \mathrm{~L}^{-1}$ solution. Exchangeable $\mathrm{Ca}, \mathrm{Mg}$, and $\mathrm{Al}$ were extracted with a $1 \mathrm{~mol} \mathrm{KCl} \mathrm{L}{ }^{-1}$ while $\mathrm{H}+\mathrm{Al}$ with a 0.5 mol calcium acetate $(\mathrm{pH} 7.0) \mathrm{L}^{-1}$. The concentrations of $\mathrm{Al}$ and $\mathrm{H}+\mathrm{Al}$ were determined by titration using a standard $0.025 \mathrm{~mol} \mathrm{NaOH} \mathrm{L}{ }^{-1}$ solution. Exchangeable $\mathrm{Ca}$ and $\mathrm{Mg}$ were determined by Atomic Absorption Spectrometry (AAS). Na and K were determined in soil extracts obtained with Mehlich-1 solution, following readings by Flame Emission Photometry (FEP).

Stalk samples were collected after harvest to quantify their nutrient uptake. Samples were pounded, dried and ground in a Willey-type mill. The concentrations of $\mathrm{N}, \mathrm{P}, \mathrm{Ca}, \mathrm{Mg}, \mathrm{K}$ and $\mathrm{Na}$ were determined according to Malavolta et al. (1997). Nitrogen was determined by sulfuric acid digestion and the semi-micro-Kjeldahl method. After nitric/ perchloric acid digestion, $\mathrm{Ca}$ and $\mathrm{Mg}$ were measured by AAS; $\mathrm{P}$ by Colorimetry; and $\mathrm{K}$ and $\mathrm{Na}$ by FEP.

Wastewater was collected 12 times during the experiment directly from the outlet of the drip irrigation system, and analyzed according to APHA (1999).

\section{Statistical analyses}

Soil and plant data were submitted to analysis of variance. The analysis presented a uniform covariant matrix, a necessary condition to carry out univariate statistical analysis for a complete block design, considering time (sampling date) as subplot. The variables which showed significant $\mathrm{F}$ test $(p<0.05)$ were submitted to mean comparisons using Tukey's test $(p<0.05)$. All statistical analyses were carried out using the SAS program, version 9.1.

\section{RESULTS AND DISCUSSION}

\section{Quality of Irrigation Water}

Water chemistry varied throughout the seasons (Table 1). The main changes occurred for $\mathrm{N}$, $\mathrm{Ca}$, $\mathrm{Na}$ and $\mathrm{K}$, with lower concentrations during the rainy summer due to a dilution effect. In comparison to the reference values, the water had a high sodium adsorption ratio (SAR), low salinity, and low concentration of $\mathrm{P}, \mathrm{Ca}$ and $\mathrm{Mg}$ (Table 1). Average values of $\mathrm{pH}, \mathrm{N}, \mathrm{Na}, \mathrm{K}$, and $\mathrm{B}$ were within commonly reported ranges for this type of water. The wastewater was not necessarily suitable for crop optimal production, with seven units of $\mathrm{Na}$ added for each unit of $\mathrm{N}$ (Table 1).

Table 2 presents some general guidelines adapted from Pescod (1992) for irrigation water quality, based mainly on salinity, sodicity and specific ion toxicity hazards. These guidelines do not take into account some important differences between sites, such as: climate, soil type, salinity tolerance of the cultivated crop, and different crop management practices. However, the present classification is still valid as it emphasizes the long-term influence of water quality on crops, soils and farm management (Ayers \& Westcot, 1985).

Table 1 - Seasonal and mean values $(n=12)$ of water quality in the experiment.

\begin{tabular}{|c|c|c|c|c|c|c|c|}
\hline \multirow{2}{*}{ Constituent } & \multicolumn{5}{|c|}{ Water } & \multirow{2}{*}{ Reference Values $^{\mathrm{a}}$} & \multirow{2}{*}{ Source } \\
\hline & Spring & Summer & Autumn & Winter & Average & & \\
\hline $\mathrm{pH}$ & 7.7 & 8.0 & 7.5 & 7.7 & 7.7 & 6.5 to 8.4 & Pescod (1992) \\
\hline $\mathrm{EC}^{\mathrm{b}}\left(\mathrm{dS} \mathrm{m}^{-1}\right)$ & 0.8 & 0.9 & 0.9 & 0.8 & 0.8 & 1.0 to 3.1 & Pescod (1992) \\
\hline Total $\mathrm{N}^{\mathrm{c}}\left(\mathrm{mg} \mathrm{L}^{-1}\right)$ & 28.7 & 28.3 & 27.5 & 33.1 & 29.4 & 10 to 50 & Feigin et al. (1991) \\
\hline $\mathrm{H}_{2} \mathrm{PO}_{4}^{-} \mathrm{P}\left(\mathrm{mg} \mathrm{L}^{-1}\right)$ & 1.9 & 3.9 & 2.2 & 1.9 & 2.5 & 4.2 to 9.7 & Bouwer \& Chaney (1974) \\
\hline $\mathrm{Ca}\left(\mathrm{mg} \mathrm{L}^{-1}\right)$ & 7.6 & 6.5 & 7.6 & 8.2 & 7.5 & 20 to 120 & Feigin et al. (1991) \\
\hline $\operatorname{Mg}\left(\mathrm{mg} \mathrm{L}^{-1}\right)$ & 1.2 & 2.0 & 2.2 & 1.8 & 1.8 & 10 to 50 & Feigin et al. (1991) \\
\hline $\mathrm{K}\left(\mathrm{mg} \mathrm{L}^{-1}\right)$ & 13.4 & 10.8 & 11.2 & 14.0 & 12.3 & 10 to 40 & Feigin et al. (1991) \\
\hline $\mathrm{Na}\left(\mathrm{mg} \mathrm{L}^{-1}\right)$ & 130 & 111 & 109 & 135 & 121 & 50 to 250 & Feigin et al. (1991) \\
\hline $\mathrm{Al}\left(\mathrm{mg} \mathrm{L}^{-1}\right)$ & 0.01 & 0.01 & 0.01 & 0.01 & 0.01 & - & - \\
\hline $\mathrm{B}\left(\mathrm{mg} \mathrm{L}^{-1}\right)$ & 0.1 & 0.1 & 0.2 & 0.2 & 0.1 & 0 to 1 & Feigin et al. (1991) \\
\hline $\mathrm{Cl}^{-} \quad\left(\mathrm{mg} \mathrm{L}^{-1}\right)$ & 58 & 67 & 67 & 74 & 66 & 40 to 200 & Feigin et al. (1991) \\
\hline $\left.\mathrm{SAR}^{\mathrm{d}}(\mathrm{mmol} \mathrm{L})^{-1}\right)^{0.5}$ & 11.6 & 9.7 & 8.9 & 11.1 & 10.3 & 4.5 to 7.9 & Feigin et al. (1991) \\
\hline
\end{tabular}

${ }^{a}$ Reference concentrations for the water constituents generally reported by different authors. ${ }^{\mathrm{b}} \mathrm{EC}$ : electrical conductivity. ${ }^{\mathrm{c}} \mathrm{Total} \mathrm{N}=(\mathrm{N}$ in the particulate matter $\left.+\mathrm{NH}_{4}^{+}-\mathrm{N}+\mathrm{NO}_{3}^{-}-\mathrm{N}+\mathrm{NO}_{2}{ }^{-}-\mathrm{N}\right)$. ${ }^{\mathrm{d}} \mathrm{SAR}$ : Sodium adsorption rate $=\mathrm{Na} / \sqrt{\mathrm{Ca}+\mathrm{Mg}}$, where $\mathrm{Na}, \mathrm{Ca}$ and $\mathrm{Mg}$ concentrations are given in $\mathrm{mmol} \mathrm{L}^{-1}$. 
According to the classification of Pescod (1992) the salinity of the water was low and not likely to affect most agricultural crops. Sugarcane, as a moderate salinity tolerant crop, is not expected to be affected by ECs below $1.0 \mathrm{dS} \mathrm{m}^{-1}$ (Maas, 1984).

The effects of effluent on soil water infiltration and permeability can be evaluated using EC and SAR (Table 2). Both SAR and EC were moderate (Table 1), with some restriction for crop production. High SAR values can be expected to cause increasing exchangeable sodium percentage (ESP), enhancing the risk of sodification associated with soil structure degradation (Balks et al., 1998).
High concentrations of $\mathrm{Na}$ indicate a moderate to severe restriction. Significant Na concentrations, together with high SAR, low EC and low Ca:Mg ratios are the main factors limiting the use of wastewater in agriculture (Fonseca, 2005). In contrast, concentrations of $\mathrm{B}$ and $\mathrm{Cl}^{-}$were not restrictive, and $\mathrm{pH}$ values were within the safe range.

Irrigation provided additional $\mathrm{N}, \mathrm{P}, \mathrm{Ca}, \mathrm{Mg}$ and $\mathrm{K}$ for crop growth, but also potentially harmful $\mathrm{Na}$ (Table 3). Secondary-treated waste water is more alkaline than other irrigation waters, and the continuous addition of $\mathrm{HCO}_{3}^{-}$and $\mathrm{CO}_{3}^{-2}$ ions can intensify the negative effects of $\mathrm{Na}$ due to the formation of $\mathrm{Ca}$ and Mg precipitates (Feigin et al., 1991).

Table 2 - Classification of water quality for irrigation, adapted from Pescod (1992).

\begin{tabular}{|c|c|c|c|}
\hline \multirow{2}{*}{ Possible Limiting Factors } & \multicolumn{3}{|c|}{ Degree of Restriction on Use } \\
\hline & None & Slight to Moderate & Severe \\
\hline \multicolumn{4}{|l|}{ Salinity } \\
\hline $\mathrm{EC}\left(\mathrm{dS} \mathrm{m}{ }^{-1}\right)$ & $<0.7$ & 0.7 to 3.0 & $>3.0$ \\
\hline Infiltration & \multicolumn{3}{|c|}{ and $\mathrm{EC}\left(\mathrm{dS} \mathrm{m} \mathrm{m}^{-1}\right)$} \\
\hline $\mathrm{SAR}=0$ to 3 & $>0.7$ & 0.7 to 2.0 & $<0.2$ \\
\hline 3 to 6 & $>1.2$ & 1.2 to 0.3 & $<0.3$ \\
\hline 6 to 12 & $>1.9$ & 1.9 to 0.5 & $<0.5$ \\
\hline 12 to 20 & $>2.9$ & 2.9 to 1.3 & $<1.3$ \\
\hline 20 to 40 & $>5.0$ & 5.0 to 2.9 & $<2.9$ \\
\hline \multicolumn{4}{|l|}{ Specific Toxicity } \\
\hline Sprinkler Irrigation - Na $\left(\mathrm{mg} \mathrm{L}^{-1}\right)$ & $<69$ & $>69$ & - \\
\hline Surface Irrigation - SAR $\left(\mathrm{mmol} \mathrm{L}^{-1}\right)^{0.5}$ & $<3.0$ & 3 to 9 & $>9.0$ \\
\hline \multicolumn{4}{|l|}{$\mathrm{Cl}\left(\mathrm{mg} \mathrm{L}^{-1}\right)$} \\
\hline Surface Irrigation & $<142$ & 142 to 355 & $>355$ \\
\hline Sprinkler irrigation & $<106$ & $>106$ & \\
\hline $\mathrm{B}\left(\mathrm{mg} \mathrm{L}^{-1}\right)$ & $<0.7$ & 0.7 to 3.0 & $>3.0$ \\
\hline $\mathrm{pH}$ & \multicolumn{3}{|c|}{ Normal Range $6.5-8.4$} \\
\hline
\end{tabular}

Table 3 - The effect of treated wastewater irrigation on the input of different nutrients and Na to the soil during the experiment.

\begin{tabular}{|c|c|c|c|c|}
\hline \multirow{2}{*}{ Constituent } & \multicolumn{4}{|c|}{ Treatments } \\
\hline & $\mathrm{T} 100$ & $\mathrm{~T} 125$ & $\mathrm{~T} 150$ & $\mathrm{~T} 200$ \\
\hline \multicolumn{5}{|c|}{ - } \\
\hline Total N & 742 & 938 & 1127 & 1497 \\
\hline $\mathrm{H}_{2} \mathrm{PO}_{4}^{-}-\mathrm{P}$ & 62 & 78 & 94 & 125 \\
\hline $\mathrm{Ca}$ & 189 & 239 & 287 & 382 \\
\hline $\mathrm{Mg}$ & 45 & 56 & 68 & 90 \\
\hline K & 311 & 393 & 473 & 628 \\
\hline $\mathrm{Na}$ & 3056 & 3860 & 4638 & 6163 \\
\hline B & 3.5 & 4.5 & 5.4 & 7.1 \\
\hline $\mathrm{Al}$ & 0.22 & 0.28 & 0.34 & 0.45 \\
\hline Total Irrigation - (mm) & 2524 & 3189 & 3832 & 5092 \\
\hline
\end{tabular}

T100-T200: Secondary-treated wastewater irrigation with 100, 125, 150 and 200\% of plant water demand. 


\section{Plant Productivity and Nutrients Uptake}

All the plots irrigated with wastewater, except the T125 treatment, had yields higher than the control without irrigation (Figure 1).

The wastewater plots received water and extra nutrients as compared with the control plots. Since all the treatments had similar concentrations of nutrients in the stalks (Table 4), it appears that the higher yields under irrigation were mainly due to the applied water. Productivity in T125 was not different when compared to the control, even though it was more than

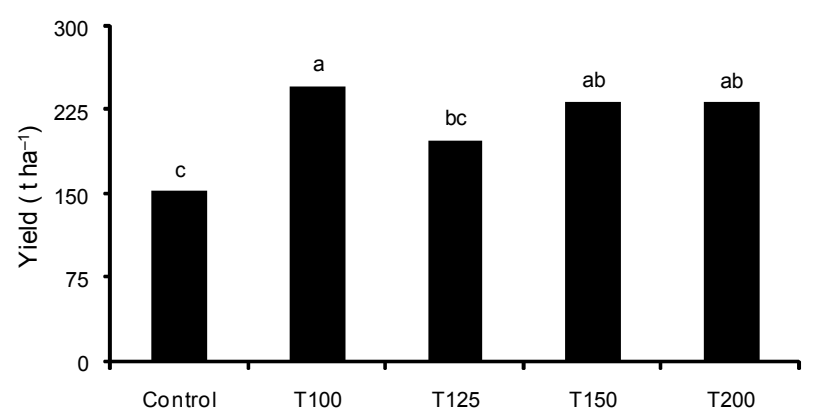

Figure 1 - Effects of treated wastewater irrigation on the sugarcane first cycle yield. Control: No irrigation and $\mathrm{N}$ mineral fertilization; T100-T200: Secondary-treated wastewater irrigation with $100,125,150$, and $200 \%$ of plant water demand. Means followed by different letters are different $(p=0.05)$.
$40 \mathrm{t} \mathrm{ha}^{-1}$ higher. It is possible that some other factors reduced the potential productivity of the T125 plots.

Average sugar cane yields of the first cut of the plant cycle in Brazil in 2005/2006 were $108 \mathrm{t} \mathrm{ha}^{-1}$ (FNP Cosultoria \& Comércio, 2006). In a field experiment using subterranean drip irrigation, Aguiar (2006) reported increased crop longevity and average yields of $155 \mathrm{t} \mathrm{ha}^{-1}$ over 8 cycles. Our data suggest that yields of 175-250 t ha ${ }^{-1}$ are possible with irrigation with wastewater and good management, at least over the short term of the first cut.

The effects of irrigation on stalk nutrient concentrations were found to be not significant $(\mathrm{N}, \mathrm{P}, \mathrm{K}$ and $\mathrm{Mg}$ ) or inconsistent ( $\mathrm{Ca}$ and $\mathrm{Na}$ ) (Table 4). Concentrations of $\mathrm{N}$ and $\mathrm{K}$ were high compared with standard values, whereas those for $\mathrm{Ca}$ and $\mathrm{Mg}$ were lower. Sugarcane extracts significant amounts of nutrients, such as $\mathrm{N}$ and $\mathrm{K}$, depending on soil type, cultivars, and climatic conditions (Demattê, 2005).

High additions of $\mathrm{N}$ and $\mathrm{Na}$ to the soil can be counterbalanced to some extent by plant growth and harvest. However, this effect is generally insufficient in reducing significantly a soil element excessive accumulation, especially of $\mathrm{Na}$ (Tillman \& Surapaneni, 2002). Elevated $\mathrm{N}$ additions by wastewater (Table 3 ), mainly at the highest irrigation rates, were also not fully

Table 4 - Effects of treated wastewater irrigation on the concentration of nutrients and $\mathrm{Na}$ in the stalks, and the uptake and recovery of nutrients and $\mathrm{Na}$ in the stalks.

\begin{tabular}{|c|c|c|c|c|c|c|}
\hline \multirow{2}{*}{ Treatments } & \multicolumn{6}{|c|}{ Stalk nutrient concentration $\left(\mathrm{kg} \mathrm{t}^{-1}\right)$} \\
\hline & $\mathrm{N}$ & $\mathrm{P}$ & $\mathrm{Ca}$ & $\mathrm{Mg}$ & $\mathrm{K}$ & $\mathrm{Na}$ \\
\hline Control & $2.26 \mathrm{a}$ & $0.17 \mathrm{a}$ & $0.09 \mathrm{~b}$ & $0.15 \mathrm{a}$ & $2.00 \mathrm{a}$ & $1.14 \mathrm{a}$ \\
\hline $\mathrm{T} 100$ & $2.16 \mathrm{a}$ & $0.18 \mathrm{a}$ & $0.15 \mathrm{a}$ & $0.19 \mathrm{a}$ & $2.21 \mathrm{a}$ & $0.55 \mathrm{~b}$ \\
\hline $\mathrm{T} 125$ & $2.33 \mathrm{a}$ & 0.18 a & $0.10 \mathrm{ab}$ & $0.19 \mathrm{a}$ & $2.23 \mathrm{a}$ & $0.61 \mathrm{~b}$ \\
\hline $\mathrm{T} 150$ & $2.25 \mathrm{a}$ & $0.20 \mathrm{a}$ & $0.12 \mathrm{ab}$ & $0.19 \mathrm{a}$ & $2.06 \mathrm{a}$ & $0.68 \mathrm{ab}$ \\
\hline \multirow[t]{4}{*}{$\mathrm{T} 200$} & $2.57 \mathrm{a}$ & $0.21 \mathrm{a}$ & $0.12 \mathrm{ab}$ & $0.20 \mathrm{a}$ & $1.98 \mathrm{a}$ & $0.74 \mathrm{ab}$ \\
\hline & \multicolumn{6}{|c|}{ Reference Values $\left(\mathrm{kg} \mathrm{t}^{-1}\right.$ stalks $\left.{ }^{-1}\right)$ Demattê, 2005} \\
\hline & 0.90 to 1.32 & 0.08 to 0.30 & 0.5 to 0.67 & 0.33 to 0.51 & 0.99 to 1.49 & - \\
\hline & \multicolumn{6}{|c|}{ Stalks nutrient uptake $\left(\mathrm{kg} \mathrm{ha}^{-1}\right)$} \\
\hline Control & 345 & 26 & 14 & 23 & 306 & 174 \\
\hline $\mathrm{T} 100$ & 534 & 44 & 37 & 47 & 546 & 136 \\
\hline T125 & 463 & 36 & 20 & 38 & 443 & 121 \\
\hline $\mathrm{T} 150$ & 524 & 47 & 28 & 44 & 479 & 158 \\
\hline \multirow[t]{2}{*}{$\mathrm{T} 200$} & 597 & 49 & 28 & 46 & 460 & 172 \\
\hline & \multicolumn{6}{|c|}{ Recovery of nutrients and $\mathrm{Na}$ ( $\mathrm{kg} \mathrm{ha}^{-1}$ in stalks $/ \mathrm{kg} \mathrm{ha}^{-1}$ applied via irrigation) } \\
\hline $\mathrm{T} 100$ & 0.72 & 0.72 & 0.20 & 1.04 & 1.76 & 0.04 \\
\hline $\mathrm{T} 125$ & 0.49 & 0.46 & 0.08 & 0.67 & 1.13 & 0.03 \\
\hline $\mathrm{T} 150$ & 0.46 & 0.50 & 0.10 & 0.65 & 1.01 & 0.03 \\
\hline T200 & 0.40 & 0.39 & 0.07 & 0.52 & 0.73 & 0.03 \\
\hline
\end{tabular}

T100-T200: Secondary-treated wastewater irrigation with 100, 125, 150 and 200\% of plant water demand. Means followed by different letters are different $(p=0.05)$. 


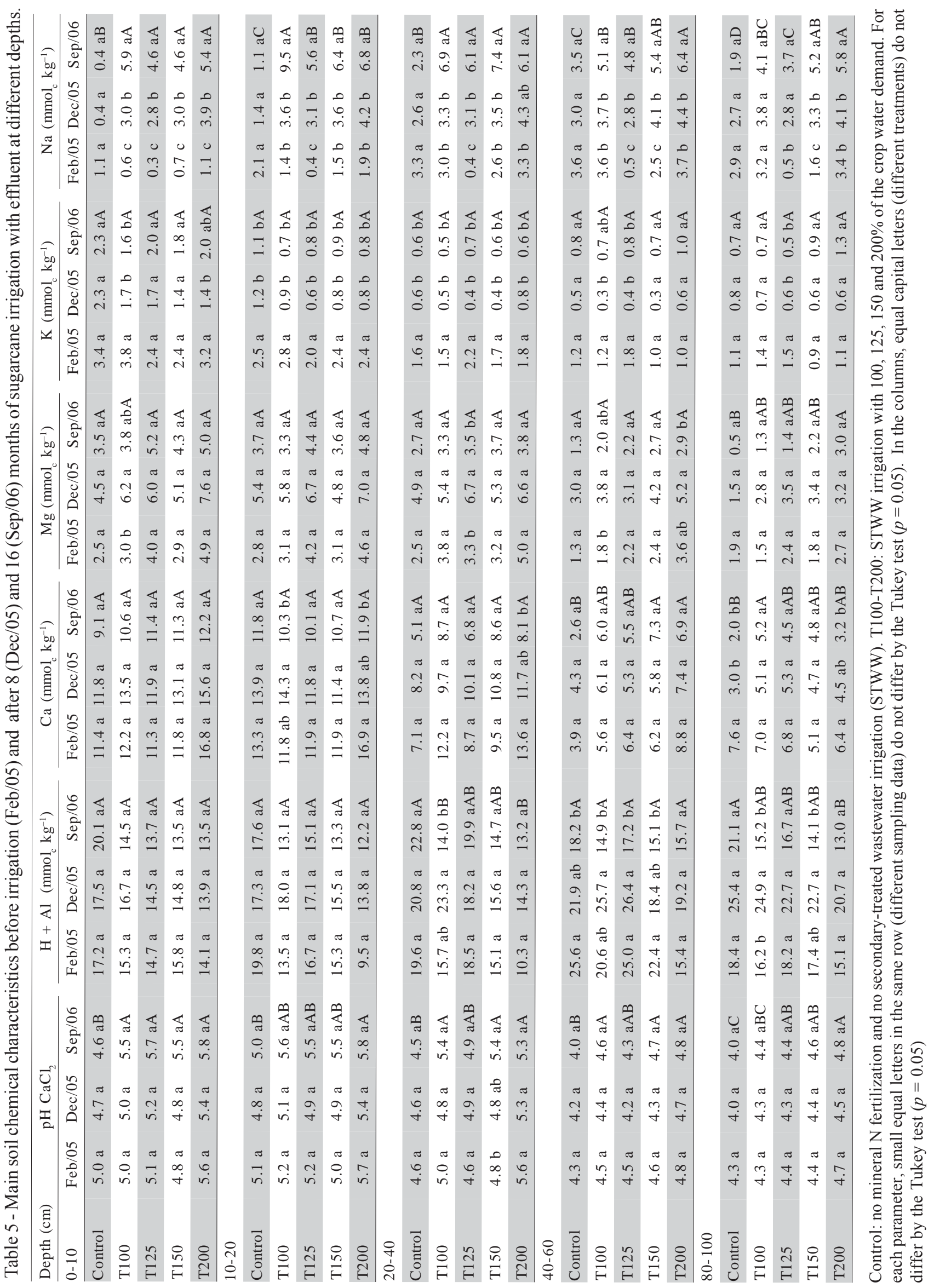


compensated by plant growth, causing a low recovery of the extra $\mathrm{N}$ applied via irrigation and resulting in a relative $\mathrm{N}$ overfertilization of the crop (Table 4).

\section{Soil exchangeable cations}

Soil $\mathrm{pH}$ at the start of the experiment was similar in the different plots (Table 5). Later on, irrigated treatments had higher $\mathrm{pH}$ values than the control at all layers, especially T200, but with little differences between each other. Small pH changes were also observed by Smith et al. (1996) in a 17-year experiment with a secondary effluent in Australia. Higher pHs under wastewater irrigation are related to the effluent alkalinity, addition of exchangeable cations and anions to the soil, and changes in $\mathrm{N}$ cycling production of $\mathrm{OH}^{-}$ions due to enhanced denitrification or nitrate reduction (Fonseca, 2005). These small changes in $\mathrm{pH}$ are not likely to directly affect crop production. There were small differences in potential acidity $(\mathrm{H}+\mathrm{Al})$ below $20 \mathrm{~cm}$ (Table 5). Irrigated treatments had lower values than the control. Differences in $\mathrm{pHs}$ discussed above may explain the higher or smaller neutralization of soil potential acidity. Decreases in exchangeable $\mathrm{Ca}$ were observed mainly for T200 over time at most soil depths (Table 5). Irrigated treatments had higher concentrations of $\mathrm{Ca}$ than the control at $40-60 \mathrm{~cm}$ and $80-100 \mathrm{~cm}$ (Table 5). Although the effluent was a significant source of $\mathrm{Ca}$ to the crop, providing up to 380 $\mathrm{kg} \mathrm{ha}^{-1}$ against a maximum uptake by the stalks of 37 $\mathrm{kg} \mathrm{Ca} \mathrm{ha}{ }^{-1}$, Ca did not accumulate in the exchangeable complex (Table 5). On the other hand, Falkiner \& Smith (1997) reported increased exchangeable calcium concentrations with effluent $\mathrm{Ca}$ additions of 230 $\mathrm{kg} \mathrm{Ca} \mathrm{ha}{ }^{-1}$ each year in a slow growing Pinus radiata plantation.

There were no differences in exchangeable $\mathrm{Mg}$ between sampling dates or between treatments at the last sampling date (Table 5). Reports for soil exchangeable $\mathrm{Mg}$ after effluent irrigation range from increases (Falkiner \& Smith, 1997), decreases (Wang et al., 2003) or inexpressive changes (Fonseca, 2005). These responses are possibly related to variations in soil natural fertility, concentrations of the nutrient in the wastewater and also to the local characteristics of production systems, with less intensive systems expected to cause increases in exchangeable $\mathrm{Mg}$ and more intensive systems a decrease (Leal, 2007; Fonseca, 2005). Moreover, in the present case, little changes were expected, once $\mathrm{Mg}$ additional input by effluent irrigation was relatively low.

Irrigation added up to $628 \mathrm{~kg} \mathrm{~K}^{-1}$ to soil. However, there were only small changes as compared with the control plots (Table 5). Soil K concentrations from $0-40 \mathrm{~cm}$ decreased in all treatments when com- pared with initial conditions. The $\mathrm{Na}$ in the effluent can possibly displace $\mathrm{K}$ and cause it to leach through the soil profile. Mixed effects for soil K concentrations under effluent irrigation have been reported (Fonseca et al., 2007). In the present case, it is assumed that most of the $\mathrm{K}$ applied was absorbed by the crop, with a maximum uptake in the stalk of $546 \mathrm{~kg} \mathrm{ha}^{-1}$.

Effluent irrigation increased soil $\mathrm{Na}$ concentrations throughout the profile when compared with initial values and also with the control plots (Table 5). Compared with other cations, $\mathrm{Na}$ has a lower affinity for the exchangeable soil complex, remaining mainly in soil solution where it can be leached. Thus the $\mathrm{Na}$ applied in the effluent easily moved to the subsoil. Increases in exchangeable $\mathrm{Na}$ after wastewater irrigation are reported widely in both agricultural and forest soils, in short and long term investigations (Fonseca et al., 2007; Toze, 2006). Bond (1998) considers that increased sodicity, together with high nitrate concentrations and salinity, are the main factors affecting the sustainability of effluent irrigation.

\section{CONCLUSIONS}

Irrigation with treated wastewater increased sugarcane yield. However, applications of wastewater above $100 \%$ of plant water demand led to no benefits in terms of crop yield and, moreover, caused problems with $\mathrm{Na}$ accumulation in the soil and potential ones for $\mathrm{N}$ offsite. Changes in $\mathrm{pH}$ and other soil exchangeable cations were of small magnitude among the treatments and over time.

Irrigation is expected to be of future importance for sugarcane cropping. The use of wastewater for irrigation purpose will require careful management and adequate technical guidelines. Once agronomic restrictions concerning optimal crop production requirements are observed, alterations provided by wastewater irrigation seem to be manageable.

\section{ACKNOWLEDGEMENTS}

To FAPESP, CNPq and the logistic support of SABESP and the agroindustry EQUIPAV.

\section{REFERENCES}

AGUIAR, F.L. Cana-de-açúcar: de gota em gota. In: FNP COSULTORIA \& COMÉRCIO. Agrianual, 2006: anuário da agricultura brasileira. São Paulo: FNP, 2006. p.227-248.

AMERICAN PUBLIC HEALTH ASSOCIATION - APHA. Standard methods for the examination for water and wastewater. 20 ed. Washington, D.C.: APHA, 1999. 1220p. AYERS, R.S.; WESTCOT, D.S. Water quality for agriculture. Rome: Food and Agriculture Organization, 1985. 174p. (Irrigation and Drainage Paper, 29). 
BALKS, M.R.; BOND, W.J.; SMITH, C.J. Effects of sodium accumulation on soil physical properties under an effluentirrigated plantation. Australian Journal of Soil Research, v.36, p.821-830, 1998.

BOND, W.J. Effluent irrigation: an environmental challenge for soil science. Australian Journal of Soil Research, v.36, p.543-555, 1998.

BOUWER, H.; CHANEY, R.L. Land treatment of wastewater. Advances in Agronomy, v.26, p.133-176, 1974.

DEMATTÊ, J.L.I. Recuperação e manutenção da fertilidade dos solos. In: Instituto da Potassa e do Fosfato. Informações agronômicas: encarte técnico. Piracicaba: Instituto da Potassa e do Fosfato, 2005. p.1-24.

EMPRESA BRASILEIRA DE PESQUISA AGROPECUÁRIA EMBRAPA. Manual de análises químicas de solos, plantas e fertilizantes. Brasília: Comunicação para Transferência de Tecnologia, 1999. 370 p.

FALKINER, R.A.; SMITH, C.J. Changes in soil chemistry in effluent-irrigated Pinus radiata and Eucalyptus grandis. Australian Journal of Soil Research, v.35, p.131-147, 1997.

FEIGIN, A.; RAVINA, I.; SHALHEVET, J. Irrigation with treated sewage effluent: management for environmental protection. Berlin: Springer, 1991. 224p.

FNP COSULTORIA \& COMÉRCIO. Agrianual, 2006: anuário da agricultura brasileira. São Paulo: FNP, 2006. p.227-248.

FONSECA, A.F. Viabilidade agronômico-ambiental da disposição de efluente de esgoto tratado em um sistema solo-pastagem. Piracicaba: USP/ESALQ, 2005. 174p. (Doutorado).

FONSECA, A.F.; HERPIN, U.; PAULA, A.M.; VICTORIA, R.L.; MELFI, A.J. Agricultural use of treated sewage effluents: agronomical-environmental implications and perspectives for Brazil. Scientia Agricola, v.64, p.194-209, 2007.

GENUTCHEN, M.T. van. A closed-form equation for predicting the hydraulic conductivity of unsaturated soils. Soil Science Society of American Journal, v.44, p.892-898, 1980.
LEAL, R.M.P. Efeito da irrigação com efluente de esgoto tratado em propriedades químicas de um latossolo cultivado com canade-açúcar. Piracicaba: USP/ESALQ, 2007. 109p. (Mestrado).

MAAS, E.V. Salt tolerance of plants. Applied Agricultural Research, v.1, p.12-36, 1984.

MALAVOLTA, E.; VITTI, G.C.; OLIVEIRA, S.A. Avaliação do estado nutricional das plantas: princípios e aplicações. 2.ed. Piracicaba: Potafos, 1997. 319p.

PESCOD, M.B. Wastewater treatment and use in agriculture. Rome: Food and Agriculture Organization, 1992. 125p. (Irrigation and Drainage Paper, 47).

RAIJ, B. van; ANDRADE, J.C.; CANTARELLA, H.; QUAGGIO, J.A. Análise química para avaliação da fertilidade de solos tropicais. Campinas: Instituto Agronômico, 2001. 285p.

RAIJ, B. van; CANTARELLA, H.; QUAGGIO, J.A.; FURLANI, A.M.C. Recomendações de adubação e calagem para o Estado de São Paulo. 2 ed. Campinas: Instituto Agronômico, 1996. 285p. (Boletim Técnico, 100).

SMITH, C.J.; HOPMANS, P.; COOK, F.J. Accumulation of Cr, Pb, $\mathrm{Cu}, \mathrm{Ni}, \mathrm{Zn}$ and $\mathrm{Cd}$ in soil following irrigation with treated urban effluent in Australia. Environmental Pollution, v.94, p.317323, 1996.

TILLMAN, R.W.; SURAPANENI, A. Some soil-related issues in the disposal of effluent on land. Australian Journal of Experimental Agriculture, v.42, p.225-235, 2002.

TOZE, S. Reuse of effluent water-benefits and risks. Agricultural Water Management, v.80, p.147-159, 2006.

WANG, Z.; CHANG, A.C.; WU, L.; CROWLEY, D. Assessing the soil quality of long-term reclaimed wastewater-irrigated cropland. Geoderma, v.114, p.261-278, 2003.

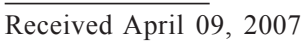

Accepted July 28, 2008 